\title{
Anthropogenic Global Warming (AGW) or Natural Global Warming (NGM)
}

\author{
Nils-Axel Mörner \\ Paleogeophysics \& Geodynamics, Stockholm, Sweden \\ Email:morner@pog.nu
}

How to cite this paper: Mörner, N.-A. (2018) Anthropogenic Global Warming (AGW) or Natural Global Warming (NGM). Voice of the Publisher, 4, 51-59. https://doi.org/10.4236/vp.2018.44005

Received: September 20, 2018

Accepted: October 15, 2018

Published: October 18, 2018

Copyright (C) 2018 by author and Scientific Research Publishing Inc. This work is licensed under the Creative Commons Attribution International License (CC BY 4.0).

http://creativecommons.org/licenses/by/4.0/

\begin{abstract}
The concept of an anthropogenic global warming (AGW) driven by the increase in atmospheric $\mathrm{CO}_{2}$ is compared to the concept of a natural global warming (NGW) driven by solar variability. The application of the AGW concept only rests on models, whilst the NGW concept rests on multiple observational and evidence-based facts. Even more so, the long-term solar variability predicts a new Grand Solar Minimum with severe climatic conditions (type Little Ice Age) to occur in 2030-2050. This violates all talk about an increasing, even accelerating, global warming. Similarly, there is no true treat of a future sea level rise flooding lowlands and islands.
\end{abstract}

\section{Keywords}

Global Warming, $\mathrm{CO}_{2}$ Forcing, Solar Forcing, Temperature, Sea Level

\section{Introduction}

Real science advances via questioning and accumulation of new observational facts. Far back in time, we left dogmatism behind. If Earth's evolution goes forward via gradualism and catastrophism, science per se, rather advances via sudden new concepts (individual "aha" or "eureka" experiences), observational facts or experiment results. It follows the path: observation-interpretation-conclusion.

In the modern new media world, fake news and falsified science may spread rapidly. This is utilized by lobbyists. The boundary between realism and falsified "facts" (fake news) becomes invisible.

It all goes back to the early 70s. The Swedish meteorologist Bert Bolin proposed the cause-and-consequence chain of increased $\mathrm{CO}_{2}$, increasing global temperature, melting glaciers and rising sea level. In 1973, the first fuel crisis happened. Olof Palme, the Swedish Prime Minister and old school friend to Bo- 
lin immediately saw new possibilities and a strong argument for leaving oil dependence and rapidly building up our nuclear power industry ("if we in 1990 do not have at least 24 nuclear power plants, it will not survive as an industrial nation"). Already in 1975, the fear of a future increase in atmospheric $\mathrm{CO}_{2}$ content was stated in the Swedish governmental declaration.

Palme realized that he would not be able to control science, so he proposed the establishment of a new intergovernmental body within the United Nation to handle the question. Prime Minister Gro Harlem Brundtland grasped the message, and put it in focus in the Brundtland Report of 1988. IPCC was born and Bolin became its first chairman with a basic mission: "to document the anthropogenic global warming"; i.e. the goal was set before the project started. The Sun was purposely left outside "because this is a project in meteorology and oceanography", he said.

So, everything was wrong all from the beginning. The IPCC reports followed every 4 years. But science was not in the centre. When I, in 1999, was the expert reviewer of the sea level chapter, I became deeply shocked. This chapter was very badly written and far below accepted reviewing standards. Furthermore, it was written by a group of 33 authors, none of which was a sea level specialist.

As a special research project of the INQUA Commission on Sea Level Changes and Coastal Evolution, I launched an International Sea Level Project in the Maldives. We rapidly obtained firm observational facts that sea level was not at all in a rapidly rising mode in the Maldives, and that it even fell by $10-20 \mathrm{~cm}$ in the 70s. The IPCC sea level story was revealed as a shameful fraud, and I published a booklet with the title The Greatest Lie Ever Told in 2007 [1].

In his book "Evidence-Based Climate Science" [2], Easterbrook concludes: Because of the absence of physical evidence that $\mathrm{CO}_{2}$ causes global warming, the only argument for $\mathrm{CO}_{2}$ as the cause of warming rests entirely in computer modelling.

\section{Climate Always Changes}

Climate always changes on the longer-term base as well as on the centennial and decadal base. From 1970 to 2000, Earth experienced a "global warming" of about $+0.6^{\circ} \mathrm{C}$. IPCC and its proponents claim that this is due to man-made $\mathrm{CO}_{2}$ emission; i.e. anthropogenic global warming (AGW). We, the climate realists, claim that this is nonsense and the all present day warming is due to normal natural variations in climate; i.e. natural global warming (NGW).

There are three ways of testing the AGW hypothesis: 1) testing relation between $\mathrm{CO}_{2}$ content and temperature by experiments, 2) looking backwards over past changes in temperature, and 3) looking forward comparing AGW-predictions with actual temperature measurements.

\subsection{Testing by Experiments}

Anthony Watts repeated Al Gore's "experiment" in support of AGW [3], and 
concluded that it was a hoax [4]. Repeated laboratory experiments under careful control by a research group in Norway fail to document that an increased $\mathrm{CO}_{2}$ content gives higher temperature when heated by light [5]. Peter Ward announced an award of 10,000 USD for the person that by experiment could verify that increased atmospheric $\mathrm{CO}_{2}$-content implies increased temperature: up to now, no one has been able to do so, however.

\subsection{Investigating past Variations in Temperature}

Global mean temperature has fluctuated over the last 170 years (Figure 1, [6]): falling by $0.6^{\circ} \mathrm{C} 1878-1910$, rising by $0.6^{\circ} \mathrm{C} 1910-1945$, falling by $0.3^{\circ} \mathrm{C}$ $1945-1975$, rising by $0.6^{\circ} \mathrm{C} 1975-2003$ and falling by $0.05^{\circ} \mathrm{C} 2003-2018$. IPCC and its proponents only consider the 1970-2000 period of temperature rise because only this period has some similarity with the rise in $\mathrm{CO}_{2}$. The rise in temperature in 1910-1940 is as big and rapid. But this rise can have nothing to do with $\mathrm{CO}_{2}$-so it is a very strong indication of non-AGW forcing. Of course, the same applies for the three periods of temperature fall. What is quite clearly documented, however, is a 60-year cyclicity. This cycle is fundamental in Earth's science [7] [8] and originates from solar forcing by Jupiter [9]. Consequently, Figure 1 graph provides a manifestation of the NGW-concept in opposite to the AGW-concept.

\subsection{Investigating Predictions}

It has become customary in the IPCC scenarios to make predictions to year 2100 $\mathrm{AD}$. With the application of 102 different $\mathrm{CO}_{2}$-driven models IPCC claims that global temperature by 2100 will rise to $+2.7 \pm 0.7^{\circ} \mathrm{C}$. The observed temperature both at Earth's surface and up in the troposphere does not agree with this, however. Rather do they indicate a temperature below to well below $+1^{\circ} \mathrm{C}$ at 2100 (Figure 2, [10]).

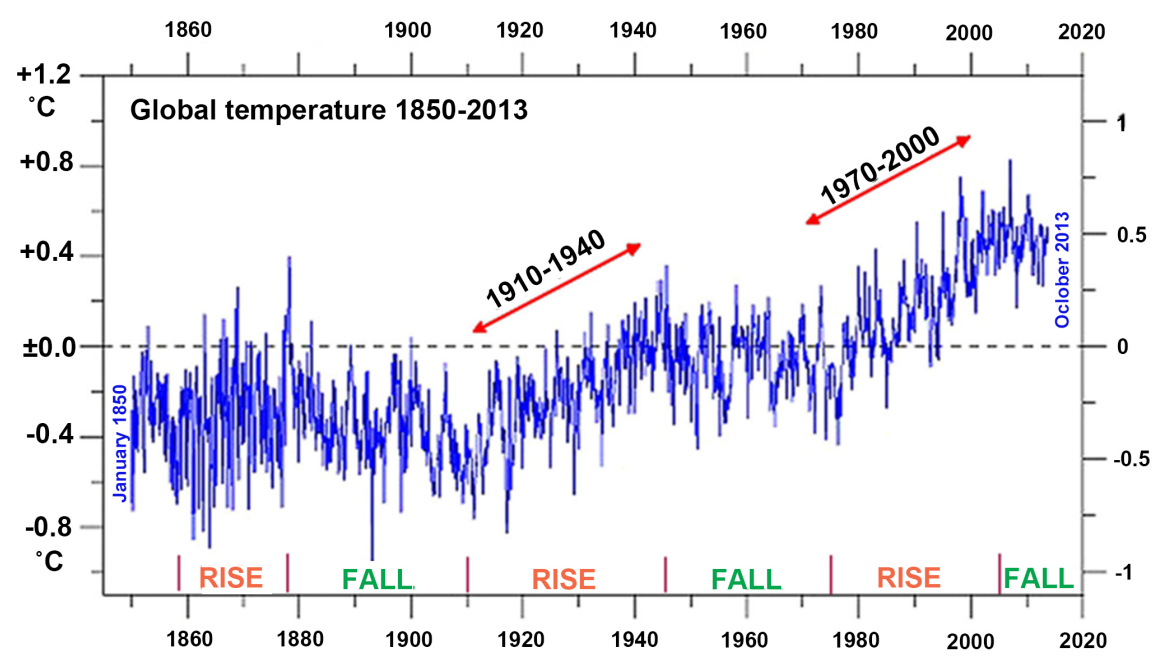

Figure 1. Cyclic changes in global temperature during the last 170 years, providing a manifestation of the NGW concept and solar forcing. 


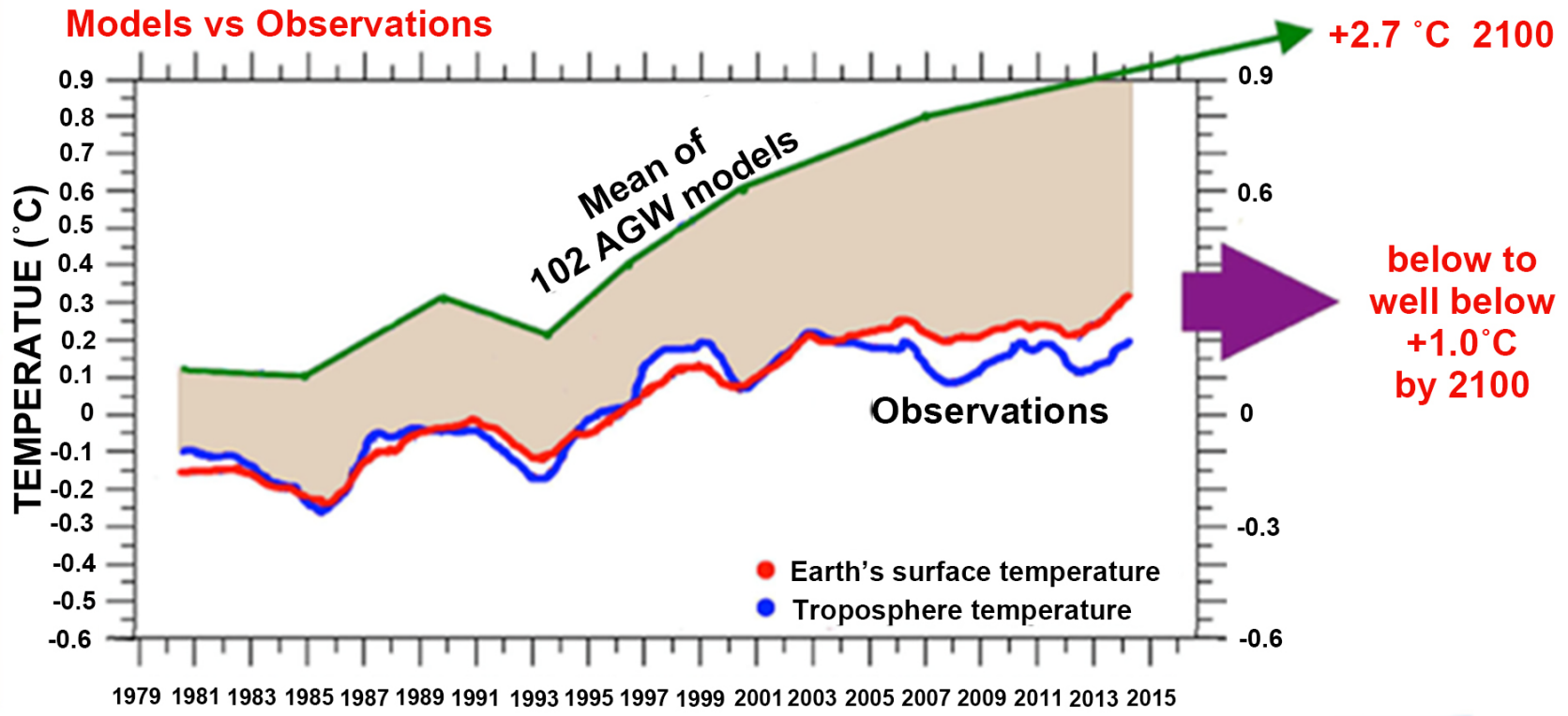

Figure 2. The AGW models of IPCC suggest a rapid rise in global temperature, which is not validated by observational measurements. This provides another strong argument for NGW, not AGW, forcing.

When observations do not fit the models, it must of course be the models that are wrong. In IPCC's weird world, it is the observational facts, however. IPCC's counter-act includes altering of observational data, contradiction of alternative views, discrediting of opponents and employment of professional lobbying firms (coining fake news like " $97 \%$ of all scientists agree", "consensus" and "science is settled").

\subsection{AGW vs. NGW}

In conclusion, all three tests of the application of the AGW hypothesis totally fail to lend any validation to this hypothesis. All three tests lend strong support to the NGW concept, however.

Under normal scientific conditions, this would be quite enough to abandon the AGW hypothesis, and turn to alternative solutions; i.e. NGW. It implies that the Paris Agreement of 2015 was based on incorrect models and a shameful ignorance of scientific facts.

Table 1 summarizes the differences in the AGW and NGW concepts. AGW is driven and maintained by populist power. Only NGW has science on its side.

Because the AGW hypothesis of IPCC is a product of United Nations, it has come to obtain a nearly unquestionable populist status, however. With no merits of its own but because of its UN (and EU) status, the AGW idea continues to advance and form the base of international and national decisions.

In 2015, an Independent Committee on Geoethics was founded [11] with the mission "to speak up and use the sword of truth when scientific facts, observational evidence and physical laws are being set aside, and when geoethical principles are violated". 
Table 1. Comparison between the AGW and NGW concepts.

\begin{tabular}{cccc}
\hline & Science & Lobbyism & Basic working means \\
\hline AGW & low \& twisted & $97 \%$ & the end justifies the means \\
NGW & $97 \%$ & unethical & the facts speak for themselves \\
\hline
\end{tabular}

\section{Solar Forcing: A Better Alternative}

We need an alternative forcing to $\mathrm{CO}_{2}$. Numerous papers and books (e.g. [2] [12]-[18]) have shown that the main driving force is the variations in solar emission of irradiance and Solar Wind (Figure 3, [12] [14]), where the solar variability is controlled by planetary beat.

\section{Sea Level Changes}

Sea level changes pose the main threat in the AGW scenario, because they claim sea level is in a rapidly rising, even accelerating, mode. This idea is based on models and twisted facts, however. In the real world, there are no traces of a rapidly rising sea level, and certainly not of an accelerating rate of sea level rise.

During the last 500 years, the eustatic changes in sea level have been dominated by the redistribution of ocean water masses over the globe; a process termed rotational eustasy [8] [19] [20] [21]. Whilst sea level over the last 70 years has remained stable (i.e. at $\pm 0.0 \mathrm{~mm} / \mathrm{yr}$ ) at the Maldives [1] [22] [23], Goa [23] [24] and Bangladesh [23] [25] in the Indian Ocean, and at Fiji [19] [26], Tuvalu [1] [23] and Vanuatu [1] in the Pacific, it has been rising at a rate of about 1.0 - $1.1 \mathrm{~mm} / \mathrm{yr}$ in northern Europe, eastern USA and northwest USA [23] [27] [28].

This implies the redistribution of ocean water masses between the northern latitudes (above Lat. $30^{\circ} \mathrm{N}$ ) and the equatorial region (between Lat. $30^{\circ} \mathrm{N}$ and $30^{\circ} \mathrm{S}$ ) on cyclic time-scales of $60 \mathrm{yr}$ and the alternations between Grand Solar Maxima and Minima [8] [19] [24]. This process can only be driven by the planetary beat on the Sun and the Earth-Moon system as shown in [8] [20] [21].

A eustatic sea level variability over the globe ranging between $\pm 0.0 \mathrm{~mm} / \mathrm{yr}$ and $1.0 \pm 0.1 \mathrm{~mm} / \mathrm{yr}$ fits perfectly well with observed changes in sea level over the last 300 years [29] [30]. Therefore, the best prediction for a sea level change at year 2100 seems to be $+5 \mathrm{~cm} \pm 15 \mathrm{~cm}$ [30], in strong disagreement to numerous models (all lacking validation in observational facts) as illustrated in Figure 4 from [31].

\section{A New Grand Solar Minimum in 2030-2050}

Several scientists (e.g. [32] [33] [34] [35] [36]) have shown that we, in fact, are approaching a New Grand Solar Minimum in about 2030-2050. In analogy with the documented climate conditions during the Spörer, Maunder and Dalton Minima, we may expect the return of a New Little Ice Age as illustrated in Figure 5 (from [34] [35]). 


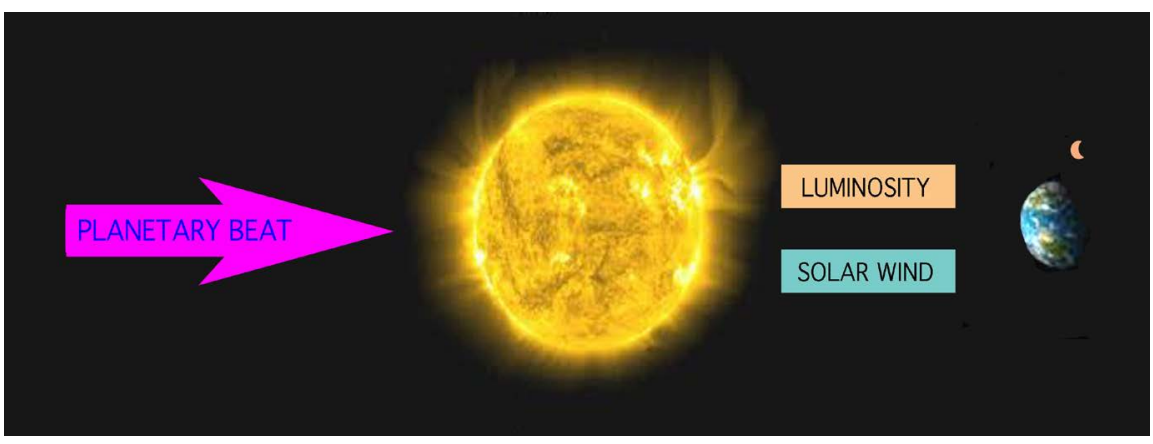

Figure 3. The concept of solar forcing [12] [14], where the planetary beat affects the solar activity and emission of irradiance and Solar Wind, which interact with Earth and its terrestrial variables.

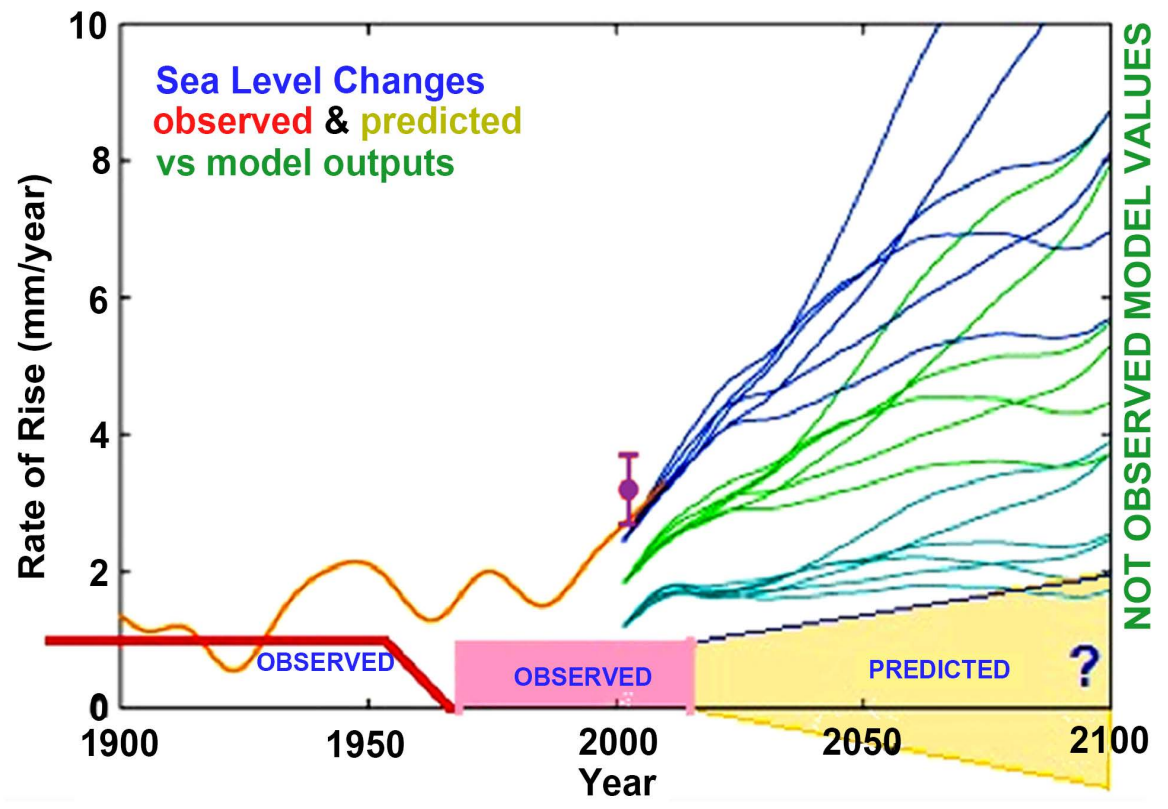

Figure 4. Observed changes in sea level during the last 150 years fluctuates at rates between \pm 0.0 and $+1.0 \mathrm{~mm} / \mathrm{yr}$, suggesting a rise by year 2100 of about $+5 \mathrm{~cm} \pm 15 \mathrm{~cm}$. Above this are model values, not validated by observations.

This implies that we, in two decades will be in the low of a New Grand Solar Minimum and in climate conditions like previous Little Ice Ages. This means just the total opposite to rapid warming of IPCC, which was the base for the Paris Agreement in 2015.

It seems a bit ironic, because, when 19 eminent scientists in 2013 concluded [13]: "This sheds serious doubts on the issue of a continual, even accelerated, warming as proposed by the IPCC", the whole journal of Pattern Recognition in Physics was closed down (see [14]).

In 1615, Galileo Galilee wrote (see [14] p. 126): "No one should be scorned in physical disputes for holding the opinions which happen to please other people best'. Still, everyone questioning the AGW hypothesis will face severe scorn from the IPCC and its proponents. 


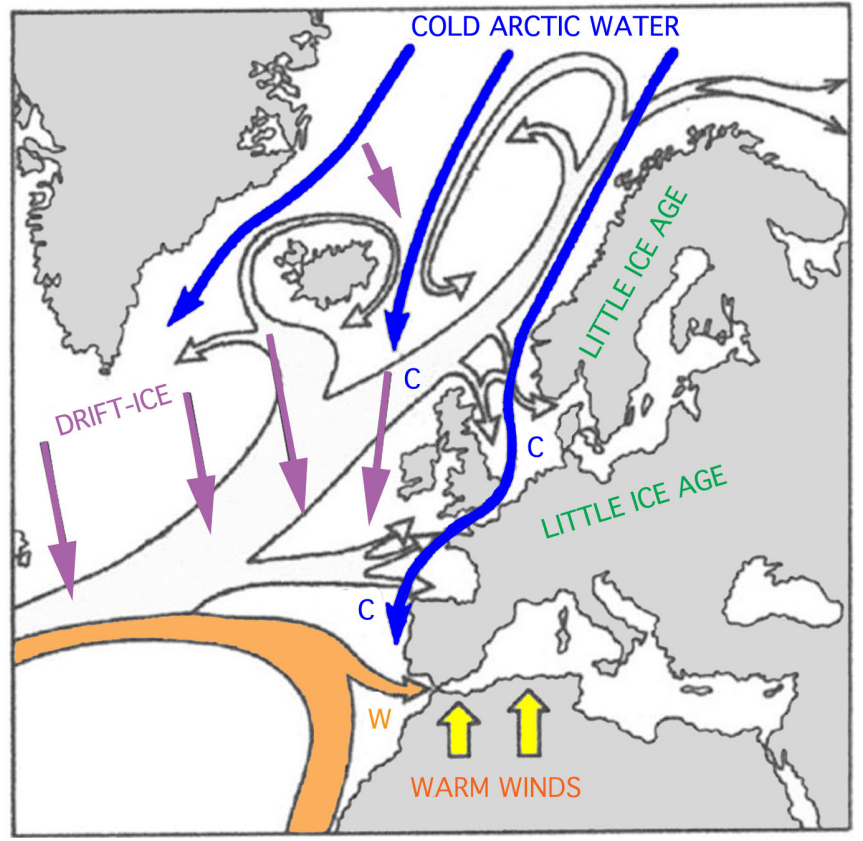

Figure 5. Observed changes in ocean circulation and climate during the Spörer (1440-1460), Maunder (1687-1703) and Dalton (1808-1821) Minima, which are likely to be repeated at the next Grand Solar Minimum in 2030-2050.

\section{Concluding Remarks}

This ends my review of the AGW idea and NGW concept. Michael Crichton, at the launching of his book State of Fear, said: "after several years of painstaking research, I came to the shocking conclusion that global warming was hot air".

I leave it to the reader to choose between the hot air of AGW and the evidence-based facts of NGW.

For me the choice is obvious. Only the NGW concept is based on science and evidence-based facts. On the personal plane, it means that all climate panic and hysteria can be put aside. On the national plane, it means that the Paris Agreement should be reconsidered.

All changes in climate and sea level are natural changes leading their origin in planetary-solar-terrestrial interaction.

\section{Conflicts of Interest}

The author declares no conflicts of interest regarding the publication of this paper.

\section{References}

[1] Mörner, N.-A. (2007) The Greatest Lie Ever Told. P\&P-Print, 20 p.

[2] Easterbrook, D.J. (2011) Evidence-Based Climate Science. Elsevier, Amsterdam, 400 p.

[3] http://www.climaterealityproject.org/climate-101 
[4] https://wattsupwiththat.com/climate-fail-files/gore-and-bill-nye-fail-at-doing-a-sim ple-co2-experiment/

[5] Solheim, J.-E., Eriksen, T. and Engebretsen, Y. (2016) A School Experiment with Radiation Heating of Small Greenhouses (in Norwegian). Fra Fysikkens Verden, 78, 78-83.

[6] Humlum, O. (2013) Kommentar til FNs klimapalels sammendrag. Report to Klimarealistene. http://www.klimarealistene.com

[7] Schlesinger, M.E. and Ramankutty, N. (1994) An Oscillation in the Global Climate System of Period 65 - 70 Years. Nature, 367, 723-726.

https://doi.org/10.1038/367723a0

[8] Mörner, N.-A. (2015) Multiple Planetary Influences on the Earth. In: Mörner, N.-A., Ed., Planetary Influence on the Sun and the Earth, and a Modern Book-Burning, Nova Science Publishers, New York, Chapter 4, 39-50.

[9] Scafetta, N. (2012) A Shared Frequency Set between the Historical Mid-Latitude Aurora Records and the Global Surface Temperature. Journal of Atmospheric and Solar-Terrestrial Physics, 74, 145-163. https://doi.org/10.1016/j.jastp.2011.10.013

[10] Mörner, N.-A. (2015) New Religion of Global Warming and Its Misconceptions in Science. Journal of Religious Studies, Buddhism and Living, 1, JBL-1-001. http://crescopublications.org/jbl/JBL-1-001.pdf

[11] Mörner, N.-A. (2015) Geoethics: The Principle of Ethics in Natural Science. Proceedings International Conference on Geoethics, Prague, 9-19 October 2015.

[12] Mörner, N.-A., Tattersall, R. and Solheim, J.-E. (2013) Pattern in Solar Variability, Their Planetary Origin and Terrestrial Impacts. Pattern Recognition in Physics, Special Issue 1, Preface, 203-204. https://doi.org/10.5194/prp-1-203-2013

[13] Mörner, N.-A., Tattersall, R., Solheim, J.-E., et al. (2013) General Conclusions Regarding the Planetary-Solar-Terrestrial Interaction. Pattern Recognition in Physics, 1, 205-206. https://doi.org/10.5194/prp-1-205-2013

[14] Mörner, N.-A., Ed. (2015) Planetary Influence on the Sun and the Earth, and a Modern Book-Burning. Nova Science Publishers, New York, 196 p.

[15] Mörner, N.-A., Monckton, C., Gregori, G.P., et al. (2015) Conclusion and Perspectives. In: Mörner, N.-A., Ed., Planetary Influence on the Sun and the Earth, and a Modern Book-Burning, Nova Science Publishers, New York, 187-190.

[16] Easterbrook, D.J. (2016) Evidence-Based Climate Science: Data Opposing $\mathrm{CO}_{2}$ Emissions as the Primary Source of Global Warming. Second Revised Edition, Elsevier, Amsterdam, $418 \mathrm{p}$.

[17] Mörner, N.-A. (2016) The London Conference Volume of Extended Abstracts \& Commentary Notes, Third Revised Edition. The London Conference on Climate Change: Science \& Geoethics, London, Volume 124. https://www.researchgate.net/publication/306013278

[18] Mörner, N.-A., Matlack-Klein, P. and Araújo, A. (2018) Basic Science of a Changing Climate: How Processes in the Sun, Atmosphere and Ocean Affect Weather and Climate. The Porto Climate Conference, Porto, 7-8 September 2018, 88 p. https://www.researchgate.net/publication/326882331

[19] Mörner, N.-A. (2017) Our Oceans-Our Future: New Evidence-Based Sea Level Records from the Fiji Islands for the Last 500 Years Indicating Rotational Eustasy and Absence of a Present Rise in Sea Level. International Journal of Earth \& Environmental Sciences, 2, 137.

[20] Mörner, N.-A. (2018) Planetary Beat and Sea Level Changes. 54-58. 
[21] The PPT of Paper [20]. https://www.researchgate.net/publication/327427281

[22] Mörner, N.-A. (2007) Sea Level Changes and Tsunamis, Environmental Stress and Migration Overseas. The Case of the Maldives and Sri Lanka. Internationales Asienforum, 38, 353-374.

[23] Mörner, N.-A. (2016) Sea Level Changes as Observed in Nature. In: Easterbrook, D.J., Ed., Evidence-Based Climate Change, Second Revised Edition, Chapter 12, Elsevier, Amsterdam, 219-231.

[24] Mörner, N.-A. (2016) Coastal Morphology and Sea Level Changes in Goa, India, during the Last 500 Years. Journal of Coastal Research, 33, 421-434.

[25] Mörner, N.-A. (2010) Sea Level Changes in Bangladesh: New Observational Facts. Energy \& Environment, 21, 235-249. https://doi.org/10.1260/0958-305X.21.3.235

[26] Mörner, N.-A. and Matlack-Klein, P. (2017) Sea Level Changes in Fiji. Journal of Aquaculture \& Marine Biology, 6, Article ID: 00170.

[27] Mörner, N.-A. (2014) Deriving the Eustatic Sea Level Component in the Kattegatt Sea. Global Perspectives on Geography, 2, 16-21.

[28] Wysmuller, T. (2016) The Fall of IPCC’s Sea Level Rise. 61-62. https://www.portoconference2018.org/presentations.html

[29] Mörner, N.-A. (2004) Estimating Future Sea Level Changes. Global Planetary Change, 40, 49-54. https://doi.org/10.1016/S0921-8181(03)00097-3

[30] Mörner, N.-A. (2011) Setting the Frames of Expected Future Sea Level Changes by Exploring Past Geological Records. 185-196.

[31] Mörner, N.-A. (2015) Natural Science Is Ruled by Observational Facts, Not Ephemeral Model Out-Puts. Global Journal of Research Analysis, 4, 193-194.

[32] Landscheidt, T. (2003) New Little Ice Age Instead of Global Warming. Energy and Environment, 14, 327-350.

[33] Charvátová, I. (2009) Long-Term Predictive Assessments of Solar and Geomagnetic Activities Made on the Basis of the Close Similarity between the Solar Inertial Motions in the Intervals 1840-1905 and 1980-2045. New Astronomy, 14, 25-30. https://doi.org/10.1016/j.newast.2008.04.005

[34] Mörner, N.-A. (2010) Solar Minima, Earth's Rotation and Little Ice Ages in the Past and in the Future. The North at Lantic-European Case. Global Planetary Change, 72, 282-293. https://doi.org/10.1016/j.gloplacha.2010.01.004

[35] Mörner, N.-A. (2015) The Approaching New Grand Solar Minimum and Little Ice Age Conditions. Natural Science, 7, 510-518.

https://doi.org/10.4236/ns.2015.711052

[36] Abdussamatov, H.J. (2016) The Little Ice Age Has Started. In: Easterbrook, D.J., Ed., Evidence-Based Climate Science, Elsevier, Amsterdam, 307-328.

https://doi.org/10.1016/B978-0-12-804588-6.00017-3 